\title{
Perbandingan Aktivitas Ekstrak Daun Kelor Dan Teh Hijau Serta Kombinasi Sebagai Antibakteri Penyebab Jerawat
}

\author{
Asri Wulandari ${ }^{{ }^{*} \text {, Yunahara Farida }}{ }^{1}$, Shelly Taurhesia ${ }^{1}$ \\ ${ }^{1}$ Program Studi Magister Farmasi, Fakultas Farmasi, Universitas Pancasila, Jakarta Selatan
}

\begin{tabular}{l}
\hline \hline \multicolumn{1}{c}{ Article info } \\
\hline History \\
Submission: 04-09-2019 \\
Review: 15-02-2020 \\
Accepted: 13-07-2020 \\
*Email: \\
asriwulan43@gmail.com
\end{tabular}

DOI: $10.33096 /$ jffi.v7i2.535

Keywords:

Moringa leaves; greentea leaves; S. aureus; P. acne

\begin{abstract}
Moringa leaves and greentea leaves have proven effective as antibacterials acne against $S$. aureus and $P$. acne. The content of moringa leaves is quercetin and greentea leaves is catechin as antibacterials. The purpose of research was to determine the antibacterial activity againts $S$. aureus and $P$. acne of moringa leaves and greentea leaves extract concentrate and combination of extract of moringa and greentea leaves with ratio 1:2, 1:1 and 2:1. Extractions were obtained using kinetic maceration method ethanol $70 \%$. Antibacterial activity was tested using hole disc diffusion method. Antibacterials test result gaints S. aureus shows that MIC of extracts of moringa and greentea leaves consicutively was 2,5\% and 1,25\% inhibition zone 8 and $7 \mathrm{~mm}$ and MIC of extracts of moringa and greentea leaves consicutively 2,5\% and 1,25\% inhibition zone 9 and $5 \mathrm{~mm}$ against $P$. acne. The best antibacterial activity of combination of extract of moringa and greentea leaves activities in ratio 1:2 against S. aureus and P. acne with inhibition zone consicutively $16 \pm 0,471 \mathrm{~mm}$ and $16 \pm 0,942 \mathrm{~mm}$. Used positive control was Mediklin ${ }^{\circledR}$ with inhibition zone $50 \mathrm{~mm}$.
\end{abstract}

\section{Pendahuluan}

Jerawat adalah penyakit kulit yang timbul akibat peradangan menahun pada folikel pilosebasea yang ditandai dengan adanya erupsi komedo, papul, pultus, nodus, dan kista pada tempat seperti muka, leher, lengan atas, dada dan punggung (Dunn et al, 2008). Radang saluran kelenjar minyak tersebut dapat mengakibatkan sumbatan pengaliran sebum yang dikeluarkan oleh kelenjar sebasea, sehingga timbul erupsi ke permukaan kulit yang dimulai dengan terjadinya komedo. Proses peradangan selanjutnya membuat komedo berkembang menjadi papul, pustul, nodus dan kista. Jika peradangan surut terjadi jaringan parut sebagai bentuk bila peradangan telah berakhir (Dunn et al, 2008). Bakteri yang mentrigger terjadinya inflamasi jerawat diantaranya $P$. acnes dan $S$. aureus, kedua bakteri ini menghasilkan enzim lipase yang dapat memecah asam lemak bebas dari lipid kulit. Asam lemak menimbulkan radang jaringan dan menyebabkan acne (Jawetz dan Adelberg, 1995). Tanaman yang secara ilmiah terbukti berkhasiat mengobati jerawat salah satunya adalah daun teh hijau (Syah, 2006; Astutiningsih dkk, 2014) dan daun kelor (Isitua et al, 2016). Daun teh hijau mengandung senyawa aktif utama katekin (Widyaningrum, 2013) sedangkan daun kelor mengandung senyawa aktif utama kuersetin yang berkhasiat sebagai antibakteri (Isitua et al, 2016; Depkes RI, 2013). Kuersetin dan katekin memiliki mekanisme kerja yang sama sebagai antibakteri penyebab jerawat yaitu dengan menghambat sintesis asam lemak pada bakteri dan menghambat produksi metabolit toksin pada bakteri (Reygaert, 2014; Siriwong et al, 2016).Hasil penelitian menunjukan bahwa ekstrak etanol daun teh hijau memiliki aktivitas antibakteri terhadap Staphylococcus aureus pada Konsentrasi Hambat Minimum (KHM) 0,05\% dan terhadap Propionibacterium acnes pada KHM 0,005\% (Lee et al, 2009). Ekstrak etanol daun kelor memiliki KHM $0,78 \%$ terhadap Propionibacterium acnes dan memiliki KHM 0,6\% terhadap Staphylococcus aureus (Hastuti et al, 2017; Ajayi et al, 2015). Berdasarkan uraian diatas, ekstrak daun kelor dan teh hijau memiliki khasiat sebagai antibakteri penyebab jerawat yang jika dikombinasikan diharapkan memberikan efektivitas yang lebih baik. Oleh karena itu perlu dilakukan penelitian untuk menguji aktivitas antibakteri penyebab jerawat ekstrak daun teh hijau dan daun kelor serta kombinasi keduanya kemudian dibandingkan aktivitas antara ekstrak tunggal dan kombinasi.

\section{Metode Penelitian \\ II.1 Pembuatan Serbuk Simplisia}

Daun kelor yang berwarna hijau tua disortasi basah tetapi tidak dilakukan pemisahan terhadap tangkainya dan ditimbang bobotnya. Daun kelor dicuci bersih dengan air mengalir lalu ditiriskan. Beberapa tangkai di ikat kemudian dibungkus kertas yang telah dilubangi. Daun kelor dikeringkan dengan cara diangin-anginkan pada suhu ruang sampai kering. Setelah kering, dilakukan sortasi kering dan dipisahkan daun dari tangkainya. 
Sedangkan daun teh hijau yang digunakan berupa simplisia kering yang siap diserbukan. Simplisia kering di haluskan dan diayak kemudian ditimbang bobot serbuk. Simplisia disimpan dalam wadah bersih, tertutup rapat, kedap udara, dan diberi silika gel.

\section{II.2 Ekstraksi Daum Kelor dan Teh Hijau}

Proses ekstraksi yang digunakan adalah maserasi kinetik dimana simplisia diekstraksi menggunakan etanol 70\%. Masing-masing serbuk simplisia dimasukan kedalam maserator kemudian ditambahkan pelarut dengan rasio 1:10 dan diaduk menggunakan alat maserator kinetik kemudian disaring menggunakan kertas saring Whatman no. 1. Proses ekstraksi dilanjutkan sampai filtrat jernih tak berwarna. Filtrat yang terkumpul diuapkan dan dipekatkan menggunakan vacuum rotary evaporator hingga terbentuk ekstrak kental.

\section{II.3 Standarisasi Mutu Ekstrak Kental \\ 1. Parameter Spesifik (Depkes RI, 2000)}

Identifikasi senyawa kimia pada Ekstrak Buah Buni (EBB) menggunakan metode Kromatografi Lapis Tipis (KLT). Fase diam yang digunakan adalah silika gel 60 F254 dan fase geraknya adalah $n$-heksan:etil asetat (2:8). Senyawa kimia yang di identifikasi adalah senyawa golongan flavonoid $\left(\mathrm{AlCl}_{3}\right)$, fenolik $\left(\mathrm{FeCl}_{3}\right.$ dan FolinCiocalteu), alkaloid (Dragendorf), dan saponin (Vanilin asam sulfat).

a. Penetapan organoleptik ekstrak meliputi bentuk, warna, bau, dan rasa.

b. Penetapan kadar senyawa terlarut dalam pelarut tertentu

1. Kadar senyawa yang larut dalam air: Sejumlah 5 g ekstrak disari selama 24 jam dengan $100 \mathrm{ml}$ air-kloroform LP, menggunakan labu bersumbat sambil berkalikali dikocok selama 6 jam pertama dan kemudian dibiarkan selama 18 jam, saring. Diuapkan $20 \mathrm{ml}$ filtrat hingga kering dalam cawan penguap, residu dipanaskan pada suhu $105^{\circ} \mathrm{C}$ hingga bobot tetap. Dihitung kadar dalam persen senyawa yang larut dalam air terhadap berat ekstrak awal.

2. Kadar senyawa yang larut dalam etanol: Sejumlah 5 g ekstrak dimaserasi selama 24 jam dengan $100 \mathrm{ml}$ etanol $95 \%$ menggunakan labu bersumbat sambil berkali kali dikocok selama 6 jam pertama dan kemudian dibiarkan selama 18 jam. Disaring cepat dengan menghindari penguapan etanol, kemudian diuapkan $20 \mathrm{ml}$ filtrat hingga kering dalam cawan penguap yang telah ditara, residu dipanaskan pada suhu $105^{\circ} \mathrm{C}$ hingga bobot tetap. Dihitung kadar dalam persen senyawa yang larut dalam etanol terhadap berat ekstrak awal.

\section{Parameter Non Spesifik (Depkes RI, 2000)}

1. Penetapan kadar air: Ditimbang seksama $1 \mathrm{~g}$ ekstrak dalam krus porselen bertutup yang sebelumnya telah dipanaskan pada suhu $105^{\circ} \mathrm{C}$ selama 30 menit dan telah ditara. Ratakan dengan menggoyangkan hingga merupakan lapisan setebal $(5 \mathrm{~mm}-10 \mathrm{~mm})$ dan dikeringkan pada suhu penetapan hingga bobot tetap, buka tutupnya, biarkan krus dalam keadaan tertutup dan mendingin dalam desikator hingga suhu kamar, kemudian dicatat bobot tetap yang diperoleh untuk menghitung persentase susut pengeringannya.

2. Penetapan kadar abu : Ditimbang 2 g ekstrak dengan seksama ke dalam krus yang telah ditara, dipijarkan perlahan lahan. Kemudian suhu di naikkan secara bertahap hingga $600 \pm 25^{\circ} \mathrm{C}$ sampai bebas karbon, selanjutnya didinginkan dalam desikator, serta timbang berat abu. Kadar abu dihitung dalam persen terhadap berat sampel awal.

3. Kadar abu yang tidak larut dalam asam: Abu yang diperoleh dari penetapan kadar abu, didihkan dengan $25 \mathrm{ml}$ asam klorida encer $\mathrm{P}$ selama 5 menit, bagian yang tidak larut asam dikumpulkan, disaring melalui kertas saring bebas abu, dicuci dengan air panas, disaring dan ditimbang, ditentukan kadar abu yang tidak larut asam dalam persen terhadap berat sampel awal.

4. Penetuan cemaran mikroba (Metode ALT): Dipipet dengan pipet steril $1 \mathrm{ml}$ ekstrak dari pengenceran $10^{-4}$, ditanamkan dalam medium PCA, lalu diinkubasi pada suhu $37^{\circ} \mathrm{C}$ selama 24 jam. Kemudian diamati dan dihitung jumlah koloni yang tumbuh dan dikalikan dengan faktor pengenceran.

5. Penentuan batas logam berat $(\mathrm{Pb})$ : Penentuan batas logam $\mathrm{Pb}$ di dalam ekstrak ditentukan dengan spektrofotometri serapan atom.

6. Penentuan residu pelarut: Penentuan batas residu pelarut di dalam ekstrak ditentukan dengan Gas Chromatography.

3. Penapisan Senyawa Fitokimia Ekstrak

1. Uji Saponin: Sejumlah 0,5 g ekstrak kental yang diperiksa ke dalam tabung reaksi, tambahkan 10 $\mathrm{mL}$ air panas. Dinginkan dan kemudian kocok kuat-kuat selama 10 detik, akan terbentuk buih yang mantap selama tidak kurang dari 10 menit, setinggi $1 \mathrm{~cm}$ sampai $10 \mathrm{~cm}$. Pada penambahan 1 tetes asam klorida $2 \mathrm{~N}$, buih tidak hilang (Depkes RI, 1980).

2. Uji Flavonoid: Sejumlah sampel ditambahkan 2-3 tetes etanol kemudian ditambahkan serbuk $\mathrm{Mg}$ dan beberapa tetes $\mathrm{HCl} 5 \mathrm{M}$. Warna merah hingga lembayung yang timbul menandakan adanya senyawa flavanon, flavonol, flavanonol, dan dihidroflavonol (Hanani, 2015).

3. Uji Tanin: Sejumlah ekstrak yang diperiksa dimasukkan ke dalam tabung reaksi, dilarutkan dengan sedikit akuades kemudian dipanaskan 
diatas penangas air. Kemudian diangkat lalu didinginkan, setelah dingin disentrifus, cairan atasnya dipisahkan dan dijadikan larutan uji. Larutan uji diteteskan dengan larutan gelatin $10 \%$, hasil positif ditandai adanya endapan putih. Pada larutan uji yang lain, ditambahkan $\mathrm{FeCl}_{3} 3 \%$, hasil positif terbentuknya warna hijau biru hingga kehitaman (Hanani, 2015).

4. Uji Alkaloid: Sejumlah ekstrak ditambah $1 \mathrm{ml}$ $\mathrm{HCl} 2 \mathrm{~N}$ dan $9 \mathrm{ml}$ air, dipanaskan selama 15 menit, didinginkan, lalu disaring. Larutan diteteskan pada kaca arloji, masing-masing ditambahkan reagen Mayer, Bouchardat, dan Dragendorff. Dicatat warna endapan (Hanani, 2015).

5. Uji Glikosida: Larutan percobaan $0,2 \mathrm{~mL}$ diuapkan diatas penangas air lalu ditambah asam asetat $3 \mathrm{~mL}$ dengan sedikit pemanasan kemudian didinginkan. Selanjutnya ditambahkan larutan $\mathrm{FeCl}_{3}$ 0,3 $\mathrm{M}$ lalu dengan hati-hati ditambahkan campuran $3 \mathrm{~mL}$ asam sulfat dan 1 tetes $\mathrm{FeCl}_{3}$ 0,3 $\mathrm{M}$ sehingga akan terbentuk cincin warna merah coklat pada batas cairan. Setelah beberapa menit diatas cincin akan berwarna biru hijau atau ungu, ini menunjukan adanya glikosida dan glikon gula 2-deoksi (Hanani, 2015).

6. Uji Steroid dan Triterpenoid: Sampel disari dengan eter, kemudian sari eter diuapkan hingga kering. Pada residu ditetesi larutan pereaksi Lieberman-Burchard. Penambahan pereaksi dilakukan dalam keadaan dingin. Terbentuknya warna ungu menunjukkan senyawa kelompok triterpenoid, sedangkan bila terbentuk warna hijau-biru menunjukkan adanya senyawa kelompok steroid (Farnsworth, 1966).

7. Uji Fenol: Sampel sebanyak 2 gram dimasukan dalam Erlenmeyer ditambahkan $10 \mathrm{~mL} \mathrm{HCl}$ 2M, dipanaskan diatas penangas air selama 30 menit kemudian disaring. Filtrat ditambahkan $20 \mathrm{~mL}$ eter dikocok dan dibiarkan hingga larutan memisah. Fase eter dipisahkan, diuapkan hingga tersisa sekitar $5 \mathrm{~mL}$. Filtrat sebanyak $1 \mathrm{~mL}$ ditambah reagen Folin Ciocalteau dipanaskan sebentar dipenangas air hingga warna berubah menjadi biru. Perubahan warna menandakan adanya kandungan senyawa fenol dalam sampel (Hanani, 2015).

\section{II.4 Uji Aktivitas Antibakteri}

Uji aktivitas antibakteri dilakukan menggunakan metode difusi agar sumuran. Media yang digunakan untuk bakteri $P$. acne adalah BHI sedangkan bakteri $S$. aureus menggunakan media TSA. Media dilarutkan dengan akuades dan disumbat menggunakan kapas steril kemudian disterilisasi dalam autoclave pada suhu $121^{0} \mathrm{C}$ selama 15 menit. Media yang telah disterilkan dituang kedalam cawan petri sebanyak $15 \mathrm{~mL}$ kemudian ditambahkan suspense bakteri $P$. acne dan $S$. aureus dengan konsentrasi masing-masing $1 \times 10^{8}$ dan $1 \times 10^{6} \mathrm{CFU} / \mathrm{mL}$ kemudian didiamkan hingga mengeras. Media yang siap digunakan dibuat sumuran dengan diameter $7 \mathrm{~mm}$, tiap cawan petri dibuat lubang sumur sebanyak 5 buah. Ekstrak daun kelor dan teh hijau masing-masing ditimbang sesuai dengan konsentrasi yang akan diuji yaitu $0.3 \%$; $0.6 \% ; 1.25 \%$; 2.5\%; $5 \%$; dan $10 \%$ kemudian dilarutkan dalam akuades steril sampai $1 \mathrm{~mL}$ lalu di vortex. Ekstrak yang sudah dipreparasi kemudian dimasukan kedalam sumuran agar sebanyak $50 \mu \mathrm{L}$ dan diberikan control positif dan control negative lalu inkubasi selama 3x24 jam. Setelah diinkubasi kemudian diukur diameter zona hambat menggunakan alat ukur yang sesuai. Kontrol positive yang digunakan adalah gel Mediklin ${ }^{\circledR}$ dan control negative akuabides steril.

\section{II.5 Analisis Data}

Data hasil pengujian aktivitas kombinasi ekstrak daun teh hijau dan daun kelor terhadap diameter zona hambat pertumbuhan bakteri Propionibacterium acne dan Staphylococcus aureus dianalisis secara statistik menggunakan metode One way anova (analisa varians satu arah) dengan program SPSS (Trial Version) dengan taraf kepercayaan $95 \%$ atau $\alpha=0,05$ menggunakan uji paired t-test.

\section{Hasil Dan Pembahasan}

\section{III.1 Hasil Pembuatan Simplisia dan Standarisasi Mutu Simplisia}

Tanaman daun teh hijau kering diperoleh dari Perkebunan Pusat Penelitian Teh dan Kina di Gambung, Ciwidey, Jawa Barat dan tanaman kelor diperoleh dari pekarangan rumah daerah Bogor Barat. Rendemen simplisia daun teh hijau sebesar 98,6\% dan daun kelor 15,2\%.

Hasil pengujian bahan organic asing terhadap simplisia rajangan daun teh hijau sebesar $0,8 \%$ dan memenuhi syarat kurang dari $2 \%{ }^{(14)}$. Kadar senyawa yang terlarut dalam etanol dari simplisia daun kelor dan teh hijau masing-masing adalah $17,30 \%$ dan $23,59 \%$ dan untuk senyawa yang larut dalam air masing-masing adalah 36,46\% dan $31,70 \%$ dan memenuhi syarat sesuai Farmakope Herbal (2013) (Depkes RI, 2013).

Hasil uji kadar air simplisia daun kelor dan teh hijau masing-masing yaitu $0,82 \%$ dan 3,06\% dan sesuai dengan syarat kadar air untuk simplisia daun yaitu kurang dari 5\%. Hasil uji kadar abu simplisia daun kelor dan teh hijau masing-masing yaitu $6,55 \%$ dan 4,55\%. Hasil yang diperoleh telah memenuhi syarat yang telah ditetapkan untuk kadar abu simplisia daun kelor dan teh hijau masing-masing kurang dari 7,5\% dan 5,6\% (Depkes RI, 2013). Nilai kadar abu tak larut asam pada simplisia daun kelor yaitu $0,73 \%$ dan untuk teh hijau tidak terdeteksi adanya abu tak larut asam dan memenuhi 
persyaratan yaitu kurang dari $0,6 \%$ dan $0,9 \%$ (Depkes RI, 2013).

Hasil uji skrining fitokimia menunjukan bahwa simplisia daun kelor dan daun teh hijau positive mengandung senyawa alkaloid, saponin, tannin, fenol, flavonoid, steroid, triterpenoid dan glikosida.

\section{III.2 Hasil Pembuatan Ekstrak dan Standarisasi Mutu Ekstrak}

Ekstrak kental daun kelor dan teh hijau diperoleh dengan metode maserasi kinetic menggunakan etanol 70\%. Rendemen ekstrak daun kelor sebesar 59,25\% sedangkan serbuk daun teh hijau sebesar 38,03\%. Ekstrak kental daun kelor memiliki karakteristik berwarna hijau kecoklatan, bau khas, dan rasa pahit sesuai dengan persyaratan. Ekstrak kental daun teh hijau memiliki karakteristik berwarna coklat kehitaman, tidak berbau dan rasa khelat sesuai dengan persyaratan (Depkes RI, 2013).

Kadar senyawa yang terlarut dalam etanol dari ekstrak daun kelor dan teh hijau masing-masing adalah $74,49 \%$ dan $81,51 \%$ dan untuk senyawa yang larut dalam air masing-masing adalah $74,12 \%$ dan $36,80 \%$. Hasil uji menunjukan bahwa senyawa dalam ekstrak lebih banyak terlarut dalam etanol dibandingkan dalam air. Kadar zat terlarut ini merupakan uji kemurnian ekstrak yang dilakukan untuk mengetahui jumlah terendah bahan kimia kandungan ekstrak yang terlarut dalam pelarut tertentu. Untuk syarat kemurnian dari simplisia maupun ekstrak minimum harus dilakukan uji penetapan kadar zat terekstraksi dalam air dan etanol.

Penetapan kadar air bertujuan untuk memberikan batasan minimal tentang besarnya kandungan air di dalam bahan (Farnsworth, 1966). Kadar air yang tinggi dapat menyebabkan pertumbuhan mikroorganisme yang akan mempengaruhi perubahan kimia pada senyawa aktif. Hasil uji kadar air ekstrak daun kelor dan teh hijau masing-masing yaitu $4,68 \%$ dan $5,53 \%$. Hasil yang diperoleh telah memenuhi syarat yang telah ditetapkan untuk kadar air ekstrak kental daun kelor dan teh hijau masing-masing kurang dari $10 \%$ dan 16\% (Depkes RI, 2013).

Prinsip penetapan kadar abu yaitu bahan yang dipanaskan pada suhu dimana senyawa organik dan turunannya terdestruksi dan menguap menjadi abu sehingga tinggal unsur mineral dan zat anorganik. Tujuan dari penetapan kadar abu yaitu memberikan gambaran kandungan mineral internal dan eksternal yang berasal dari proses awal sampai terbentunya ekstrak (Depkes RI, 2000). Hasil uji kadar abu ekstrak daun kelor dan teh hijau masingmasing yaitu $6,10 \%$ dan $1,88 \%$. Hasil yang diperoleh telah memenuhi syarat yang telah ditetapkan untuk kadar abu ekstrak kental daun kelor dan teh hijau masing-masing kurang dari 9,0\% dan 2,0\% (Depkes RI, 2013). Penetapan kadar abu tak larut asam menunjukan banyaknya pasir dan silika yang ada dalam suatu sampel. Nilai kadar abu tak larut asam pada ekstrak daun kelor dan teh hijau masing-masing yaitu $0,48 \%$ dan $0,02 \%$ dan memenuhi persyaratan yaitu kurang dari $0,9 \%$ dan 0,4\% (Depkes RI, 2013).

Pengujian cemaran bakteri termasuk salah satu uji untuk syarat kemurnian ekstrak. Uji ini mencakup penentuan jumlah mikroorganisme yang diperbolehkan dan untuk menunjukan tidak adanya bakteri tertentu dalam ekstrak. Cemaran mikroba pada ekstrak kelor dan teh hijau masing-masing 9,2 x $10^{3} \mathrm{koloni} / \mathrm{g}$ dan $9,5 \times 10^{3}$ dan berada dibawah batas maksimum persyaratan mutu bahan baku obat tradisional yaitu $10^{6}$ koloni/g. Rendahnya pertumbuhan bakteri ini juga bisa disebabkan karena ekstrak yang digunakan adalah ekstrak etanol, dimana etanol juga dapat menghambat pertumbuhan bakteri atau mikroba dalam ekstrak (BPOM, 2014).

Hasil pengujian cemaran logam berat $\mathrm{Pb}$ menunjukan bahwa dalam ekstrak daun kelor dan teh hijau tidak terdapat kandungan logam berat $\mathrm{Pb}$. Menurut BPOM kandungan $\mathrm{Pb}$ dalam ekstrak kurang dari $10 \mathrm{mg} / \mathrm{kg}$ atau $10 \mathrm{ppm}$, adanya timbal $\mathrm{Pb})$ dalam sampel dapat disebabkan oleh proses pengeringan simplisia yang akan digunakan sebagai tanaman obat. Pengeringan dengan sinar matahari langsung di udara terbuka dapat menyebabkan simplisia tersebut mengalami pencemaran lingkungan termasuk logam berat timbal $(\mathrm{Pb})$ (Hernani dan Nurdjanah, 2009). Pencemaran lingkungan tersebut dapat berasal dari limbah industri maupun bahan bakar kendaraan bermotor yang mengandung timbal $(\mathrm{Pb})$ dan keluar dari knalpot sehingga menyebabkan polusi di sekitar tempat pengeringan simplisia tersebut. Adanya timbal $(\mathrm{Pb})$ yang terkandung dalam air yang digunakan untuk irigasi dalam pertanian juga dapat menyebabkan cemaran timbal $(\mathrm{Pb})$ dan kadmium (Cd) dalam tanaman (Sudarmaji et al, 2006).

Pengujian sisa residu pelarut bertujuan memberikan jaminan bahwa selama proses tidak meninggalkan sisa pelarut yang seharusnya tidak boleh ada dan nilai yang dihasilkan menunjukan tingkat kemurnian suatu sampel. Pelarut yang dimaksud adalah etanol (Depkes RI, 2000). Sisa residu pelarut yang terdapat dalam ekstrak kental etanol daun kelor dan teh hijau masing-masing yaitu $0,2859 \%$ dan $0,1946 \%$. Hasil yang diperoleh telah memenuhi syarat sisa residu pestisida untuk ekstrak tanaman tidak lebih dari $1 \%$.

\section{III.3 Hasil Penapisan Senyawa Fitokimia Ekstrak}

Hasil penapisan senyawa fitokimia dalam ekstrak daun kelor dan teh hjau menunjukan positif mengandung senyawa alkaloid, saponin, tannin, fenol, flavonoid, steroid, triterpenoid dan glikosida. Beberapa hasil penelitian ilmiah membuktikan bahwa ekstrak daun kelor mengandung tannin, alkaloid, saponin, flavonoid, steroid, triterpenoid dan glikosida (Roopalatha dan Mala, 2013) 
sedangkan ekstrak daun teh hijau mengandung senyawa flavonoid, fenol, alkaloid, glikosida (Bashir et al, 2014), tannin, dan saponin (Andrayekti et al, 2015).

\section{III.4 Hasil Uji Aktivitas Antibakteri Ekstrak}

Uji aktivitas antibakteri ekstrak daun kelor dan teh hijau serta kombinasi ekstrak daun kelor dan teh hijau terhadap bakteri $P$. acne dan $S$. aureus menggunakan metode difusi agar dengan cara sumuran. Hasil uji aktivitas antibakteri menunjukan bahwa ekstrak daun teh hijau memiliki aktivitas antibakteri terhadap $P$. acne dan $S$. aureus yang lebih baik dibandingkan ekstrak daun kelor, hal ini dilihat dari konsentrasi hambat minimum dan zona hambat yang dihasilkan. Kontrol positive yang digunakan Mediklin ${ }^{\circledR}$ dengan zona hambat $50 \mathrm{~mm}$ dan control negative yang digunakan akuabides steril dengan zona hambat $0 \mathrm{~mm}$. Hasil pengukuran rata-rata diameter zona hambat dapat dilihat pada Tabel 1 dan Tabel 2.

Tabel 1. Aktivitas antibakteri ekstrak daun kelor dan teh hijau

\begin{tabular}{|c|c|c|c|c|c|c|c|}
\hline \multirow{2}{*}{ Sampel } & \multirow{2}{*}{ Bakteri } & \multicolumn{6}{|c|}{ Diameter zona hambat $(\mathrm{mm}) \pm \mathrm{SD}$} \\
\hline & & $0,3 \%$ & $0,6 \%$ & $1,25 \%$ & $2,5 \%$ & $5 \%$ & $10 \%$ \\
\hline \multirow[t]{2}{*}{ Ekstrak daun kelor } & P. acne & $0 \pm 0$ & $0 \pm 0$ & $0 \pm 0$ & $9 \pm 0$ & $12 \pm 0$ & $14 \pm 0$ \\
\hline & S. aureus & $0 \pm 0$ & $0 \pm 0$ & $0 \pm 0$ & $8 \pm 0$ & $12 \pm 0$ & $14 \pm 0$ \\
\hline \multirow[t]{2}{*}{ Ekstrak daun teh hijau } & P. acne & $0 \pm 0$ & $0 \pm 0$ & $5 \pm 0$ & $13 \pm 0$ & $18 \pm 0$ & $24 \pm 0$ \\
\hline & S. aureus & $0 \pm 0$ & $0 \pm 0$ & $7 \pm 0$ & $15 \pm 0$ & $17 \pm 0$ & $20 \pm 0$ \\
\hline
\end{tabular}

Tabel 2. Aktivitas antibakteri kombinasi ekstrak daun kelor dan teh hijau

\begin{tabular}{ccc}
\hline Kombinasi Ekstrak & \multicolumn{2}{c}{ Diameter zona hambat $(\mathrm{mm}) \pm$ SD } \\
\cline { 2 - 3 } Daun Teh Hijau : Kelor & P. acne & S. aureus \\
\hline $1,25 \%: 2,5 \%$ & $16 \pm 0,942$ & $16 \pm 0,471$ \\
$2,5 \%: 2,5 \%$ & $24 \pm 0$ & $23 \pm 0,471$ \\
$5 \%: 2,5 \%$ & $30 \pm 0$ & $29 \pm 0$ \\
\hline
\end{tabular}

Uji aktivitas antibakteri kombinasi bertujuan untuk mengetahui aktivitas antibakteri yang dimiliki oleh kombinasi ekstrak daun kelor dan teh hijau terhadap bakteri $P$. acne dan $S$. aureus dan hasil yang diperoleh dapat bersifat sinergis atau antagonis. Aktivitas antibakteri kombinasi ekstrak bersifat sinergis jika efek dari kombinasi memiliki zona hambat yang lebih besar dibandingkan dengan efek antibakteri pada ekstrak tunggal sedangkan bersifat antagonis jika efek kombinasi yang diperoleh zona hambat lebih kecil atau sama dengan efek tunggal (Astri, 2015).

Analisis uji paired t-test dilakukan untuk melihat perbedaan luas zona hambat antibakteri yang dihasilkan oleh ekstrak daun kelor dan teh hijau secara tunggal dibandingkan dengan ekstrak yang dikombinasi dengan berbagai konsentrasi. Interpretasi hasil analisis yaitu nilai signifikan $<0,05$ maka terdapat perbedaan yang nyata pada luas zona hambat yang dihasilkan oleh ekstrak tunggal dan kombinasi. Nilai signifikansi $>0,05$ menunjukan bahwa bahwa tidak ada perbedaan yang nyata pada luas zona hambat yang dihasilkan oleh ekstrak tunggal dan kombinasi. Hasil analisis yang diperoleh memiliki nilai signifikansi $<0,05$ pada ekstrak daun kelor dan teh hijau dan kombinasi ekstrak terhadap bakteri penyebab jerawat $P$. acne dan $S$. aureus. Variasi konsentrasi ekstrak daun kelor dan teh hijau dan kombinasi ekstrak memberikan hasil yang berbeda nyata dengan melihat luas zona hambat yang dihasilkan.
Perbedaan tersebut dapat disebabkan semakin tinggi konsentrasi ekstrak maka semakin luas zona hambat karena kandungan senyawa aktif antimikroba yang terkandung dalam ekstrak berpengaruh terhadap daya hambat yang dihasilkan. Kombinasi ekstrak daun kelor dan teh hijau memberikan efek yang sinergis karena zona hambat yang dihasilkan lebih tinggi dibandingkan aktivitas antibakteri ekstrak secara tunggal.

Kandungan senyawa utama yang berkhasiat sebagai antibakteri pada ekstrak daun kelor memiliki mekanisme kerja yang sama dengan kandungan senyawa utama katekin pada ekstrak daun teh hijau. Kuersetin merupakan golongan senyawa flavonol yang memiliki mekanisme kerja antibakteri dengan menghambat sintesis peptidoglikan yang mengakibatkan kerusakan morfologi bakteri, menghambat aktivitas $\beta$ laktamase, menghambat sintesa asam lemak, tetapi meningkatkan protein amida I dan II pada sel bakteri (Siriwong et al, 2016). Ekstrak etanol daun kelor juga memiliki efek anti inflamasi dengan mengurangi udem dilanjutkan dengan analisis ekspresi COX-2 melalui pengamatan sel neutrophil (Sulistyawati dan Pratiwi, 2016) dan dapat dimanfaatkan sebagai salah satu alternative pengobatan jerawat. Katekin dalam ekstrak daun teh hijau memiliki efek antimikroba langsung dengan mekanisme kerja merusak membrane sel bakteri, menghambat sintesa asam lemak dan penghambatan aktivitas enzim. Efek lain yang dapat berkontribusi 
terhadap efek antimikroba keseluruhan pada individu yang terinfeksi dapat menghambat peradangan (terutama peradangan yang disebabkan oleh stres oksidatif, seperti vaskular) dengan meningkatkan sintesis oksida nitrat (Reygaert, 2014).

\section{Kesimpulan}

Hasil uji aktivitas antibakteri ekstrak daun kelor dan teh hijau dan kombinasi ekstrak pada berbagai konsentrasi memberikan perbedaan nyata terhadap bakteri penyebab jerawat $P$. acne dan $S$. aureus dengan melihat luas zona hambat yang dihasilkan pada setiap konsentrasi ekstrak tunggal dan kombinasi. Hasil uji aktivitas antibakteri terhadap $S$. aureus menunjukan bahwa KHM ekstrak daun kelor dan daun teh hijau berturut-turut adalah 2,5\% dan 1,25\% dengan zona hambat $8 \mathrm{~mm}$ dan $7 \mathrm{~mm}$ dan KHM ekstrak daun kelor dan daun teh hijau berturut-turut $2,5 \%$ dan $1,25 \%$ terhadap $P$. acne adalah dengan zona hambat $9 \mathrm{~mm}$ dan $5 \mathrm{~mm}$. Aktivitas antibakteri terbaik kombinasi ekstrak daun teh hijau dan kelor pada rasio 1:2 terhadap bakteri $S$. aureus dan $P$. acne dengan zona hambat berturutturut $16 \pm 0,471 \mathrm{~mm}$ dan $16 \pm 0,942 \mathrm{~mm}$.

\section{Daftar Pustaka}

Ajayi AO \& Fadeyi TE. (2015). Antimicrobial Activities and Phytochemical Analysis of Moringa oleifera Leaves on Staphylococus aureus and Streptococcus species. AJPCT, 3; 10 643-653.

Andrayekti R, Mufrod \& Munisih S. (2015). Pengaruh Basis Gel Sediaan Masker Ekstrak Daun Teh Hijau (Camellia sinensis Linn.) Pada Karakteristik Fisik Dan Aktivitas Antibakteri S. aureus ATCC 25923. Majalah Farmaseutik, 11 (2).

Astutiningsih C, Setyani W \& Hindratna H. (2014). Uji Daya Antibakteri dan Identifikasi Isolat Senyawa Katekin Dari Daun Teh (Camellia sinensis L. var Assamica). Jurnal Farmasi Sains dan Komunitas, 11 (2).

Astri DY. (2015). Aktivitas Antibakteri Kombinasi Ekstrak Etanol Biji dan Batang Pepaya (Carica papaya L.) Terhadap Staphylococcus epidermidis dan Shigella sonnei. Naskah Publikasi. Universitas Muhammadiyah Surakarta. p. 1-9.

Badan Pengawas Obat dan Makanan. (2014). Peraturan Kepala BPOM Indonesia Nomor 12 Tahun 2014 Tentang Persyaratan Mutu Obat Tradisional. Jakarta.

Bashir S, Khan BM, Babar M, Andleeb S, Hafeez M, Ali S \& Khan MF. (2014). Assesment of Bioautography and Spot Screening of TLC of Green Tea (Camellia) Plant Extracts as Antibacterial and Antioksidan Agents. Indian J.Pharm Sci, 74 (4). p. 364370 .
Departemen Kesehatan RI. (1980). Materia Medika Indonesia Jilid IV. Jakarta.

Departemen Kesehatan Republik Indonesia. (2000). Parameter Standar Umum Ekstrak Tumbuhan Obat Edisi I. DirJen POM. Jakarta.

Departemen Kesehatan Republik Indonesia. (2013). Farmakope Herbal Indonesia. p 64-65.

Dunn J A, Robert A C, Richatd T, Enas, Robert J G. (2008). Novel Topically Active Antimicrobial and Anti-Inflammatorry Compounds For Acne. In: Walters, Kenneth A, editor. Dermatologic, Cosmoceutic And Cosmetic Development. New York: Informa Healthcare. h 243.

Farnsworth NR. (1966). Biological and Phytochemical Screening of Plants. J.Pharm.Sci, 55; 3. p. 225-269.

Hanani E. (2015). Analisis Fitokimia. EGC Press: Jakarta.

Hastuti NS, Taurhesia S \& Wibowo AE. (2017). Aktivitas Secara In Vitro dan In Vivo Kombinasi Ekstrak Daun Kelor (Moringa oleifera Lam.) dan Pegagan (Centella asiatica (L). Urb.) Sebagai Gel Antijerawat. Majalah Farmasi.

Hernani \& Nurdjanah R. 2009. Perkembangan Teknologi Tro. 21 (2), 33-39.

Isitua CC, Ibeh IN \& Olayinka JN. (2016). Antibacterial Activity Of Moringa oleifera Lamk. Leaves on Enteric Human Pathogens. Indian Journal of Applied Research, 6 (9) : 553-556. ISSN 2249$555 \mathrm{X}$.

Jawetz M \& Adelberg. (1995). Mikrobiologi Kedokteran Edisi XX Terjemahan Nugroho Edi dan Maulany FF. Jakarta. EGC. p. 208, 291.

Lee JH, Shim JS, Mi-Sook Chung, Lim ST \& Kim KH. (2009). In Vitro Anti-Adhesive Activity of Green Tea Extract against Pathogen Adhesion. Phytother. Res, 23, 460-466.

Roopalatha UC, Mala V. (2013). Phytochemical Analisis of Succesive Reextracts of The Leaves of Moringa oleifera Lamk. Int $J$ Pharm Pharm Sci, 5 (3). p. 629-634.

Reygaert WC. (2014). The Antimicrobial Possibilities of Green Tea. Frontiers in Microbiology, 5 (434).

Siriwong S, Teethaisong Y, Thumanu K, Dunkhunthod B, Eumkeb G. (2016). The Synergy and Mode of Action of Quercetin Plus Amoxicillin Against AmoxicillinResistant Staphylococcus epidermidis. BMC Pharmacology and Toxicology,17 (39). DOI 10.1186/s40360-016-0083-8.

Sudarmaji, Mukono J \& Corie I.P. (2006). Toksikologi Logam Berat B3 dan 
Dampaknya Terhadap Kesehatan. Jurnal Kesehatan Lingkungan, 2 (2). p. 129-142. Sulistyawati R \& Pratiwi PY. (2016). Pengaruh Pemberian Ekstrak Etanol Daun Kelor (Moringa oleifera L.) Terhadap Aktivitas Analgesik dan Antiinflamasi Melalui Ekspresi Enzim Siklooksigenase. Pharmaciana, 6 (1). p. 31-38.

Syah A. 2006. Taklukan Penyakit dengan Teh Hijau Cetakan 1. Agromedia Pustaka. Jakarta. p 4.

Widyaningrum N. (2013). Epigallocatechin-3Gallate (EGCG) Pada Daun Teh Hijau Sebagai Antijerawat. Majalah Farmasi dan Farmakologi, 17 (03). 